\title{
How to Choose the European Executive:
}

\section{A Counterfactual Analysis, 1979-1999}

\author{
Simon Hix \\ London School of Economics and Political Science
}

Abdul Noury

Université Libre de Bruxelles

Gérard Roland

University of California, Berkeley, CEPR and WDI

\begin{abstract}
:
In this paper, we use data on roll-call votes by MEP's in the five elected European Parliaments $(1979,1984,1989,1994,1999)$ to evaluate the likely impact of current proposals in the Convention on the Future of Europe for the appointment of the European executive. We find (a) that the different procedures for appointing the Commission lead to quite different results in terms of the composition of the Commission, (b) that election of the President of the Commission by the national parliaments (our preferred mode of appointment) gives the result that is most in line with the observed composition of the Commission since 1979, whereas (c) election by the European Parliament creates a 'built-in' form of divided government between the Council and the Commission that could prove counterproductive for the functioning of European institutions.
\end{abstract}




\section{Introduction}

A key issue in the design of any constitution is how to (s)elect the executive. It is no surprise, then, that one of the most controversial issues in the Convention on the Future of Europe is how to elect the EU's executive: the European Commission. Several governments, such as the British and French, would like to maintain the institutional status quo as established by the Nice Treaty - whereby the Commission is elected by (a qualified-majority of) the EU Heads of Government (Blair, 2002). Against the institutional status quo, the 'parliamentary' model, where the executive is 'fused' to a majority in the EU legislature, seems to be the most popular. For example, Germany and the Benelux have proposed that the Commission should be elected by the European Parliament (Fischer, 2000; Brok, 2002; Verhofstadt, 2002). Also, the Commission has proposed that it should be elected by a two-thirds majority in the European Parliament (Commission of the EU, 2002). More recently, the Chirac-Schroeder 'compromise' proposal to have the Commission President elected by the European Parliament and a Council President elected by the Council has been gaining strong momentum. So far, only the Irish government has considered a 'presidential' model (Laver et al., 1995), where the Commission would be elected separately from the European Parliament - either directly by the voters or indirectly by an electoral college of national parliaments (cf. Hix, 2002b; Berglöf et al., 2003).

The pros and cons of the parliamentary and presidential models of government are well-rehearsed in the political science and political economy literature (e.g. Lijphart, 1992). Essentially, presidential government allows for true separation of powers between the executive and legislative branch of government. With a formal separation-of-powers, the executive is unable to force the legislative majority to support its policy agenda (Shugart and Carey, 1992), but the executive cannot be brought down by a vote of confidence in the 
legislature. In contrast, with a fusion of the legislative and executive majorities, the executive can force its parliamentary parties to support its policy agenda by threatening to resign, and hence risk a battle over the formation of a new executive (Huber, 1996; Diermeier and Feddersen, 1997). This often means less policy change with a separation-of-powers than with parliamentary government (Tsebelis, 2002). Also, parliamentary governments tend to produce more public goods but also a higher size of government and more rents to politicians than presidential government (cf. Persson, Roland and Tabellini, 1997, 2000). Parliamentary government also tends to lead more easily to creeping policy centralization (Bednar et al., 2001).

Rather than rehearse these theoretical debates in the EU context (cf. Crombez and Hix, 2002), we do something completely different: we undertake a counterfactual analysis of how EU politics would have worked had different models of executive election been used in the EU since 1979. In this counterfactual analysis we use data from voting in the European Parliament. In previous research we have collected and analysed the total population of rollcall votes in the European Parliament between 1979 and 2001: approximately 12,000 votes by 2,000 MEPs (Hix, Noury and Roland, 2002). From these votes we calculate ideal point estimates for every Member of the European Parliament (MEP) on the two main dimensions of EU politics (the left-right, and pro-/anti-integration), using the NOMINATE algorithm developed by Keith Poole and Howard Rosenthal (Poole and Rosenthal, 1997).

We use the ideal points of the MEPs to model election of the Commission President by the European Parliament in each of the five directly-elected parliaments. We calculate the partisan affiliation of the Commission President under several election procedures and different assumptions about MEPs' voting behaviour. First, we allow each parliament to elect a single Commission President (who would then presumably put the rest of his/her team together, in cooperation with the governments). This corresponds essentially to the 
"federalist" proposal for the Convention supported by Germany, the Benelux countries and supporters of a federalist Europe. In one scenario we assume that MEPs follow the 'whip' of their party groups. In an alternative scenario, we assume that MEPs vote according to their individual policy position vis-à-vis the candidates.

Second, we model the process of government formation in each parliament. The purpose is to simulate what kinds of government a fully-fledged parliamentary Europe would produce. While this scenario is not currently on the table, this is seen as a long-term desirable scenario by many. Here we either assume that a government requires the support of fiftypercent-plus-one MEPs or that a government requires the support of two-thirds of MEPs, as in the proposal by the Commission to the Convention.

We then contrast the outcomes of these different parliamentary models of EU government with what would have happened had a presidential model existed. Here we assume that the Commission President is elected by an electoral college of national parliaments in the same year as a European Parliament election (Hix, 2002b). This can be seen as a realistic scenario for a presidential model of Europe as the direct election of a European president is not being considered as a likely scenario in the current situation. ${ }^{1}$ We compare these counterfactual parliamentary and presidential models with the real-world outcomes: the partisan make-up of the seven Commissions that were appointed between 1979 and 1999.

One must of course be cautious with such a counterfactual exercise since it assumes implicitly that political agents (MEPs, members of national parliaments) behave the same way under a different institutional setup. We know this is not the case. Nevertheless, given the uncertainty surrounding the effects of any possible institutional change in the context of

\footnotetext{
${ }^{1}$ Note that the first American Presidents were chosen by an electoral college constituted mostly by votes in the state legislatures. It is only later that universal suffrage became the norm for choosing the electoral college. Berglöf et al. (2003) argue that the Hix (2002b) proposal is the best suited for an evolutionary approach towards a presidential model of governance for Europe.
} 
Europe, we consider it useful to use all the available data to shed light on the effects of various proposals for the selection of the European executive. Our database on roll-call votes in the European Parliament can serve exactly this purpose. We feel that such a counterfactual empirical analysis, which uses a comprehensive dataset of observed behaviour, goes much further than mere speculation.

The main insights from this exercise are as follows. The composition of the Commission or the political colour of its president would have been different under the different proposals before the Convention. If the Commission President had been elected by the national parliaments, a centre-right politician would have been elected between 1979 and 1999, and a centre-left politician in 1999. In contrast, a rather different Commission President would have been elected if a parliamentary model had been used. If the EP elected the Commission President directly, the 1994 centre-right Santer Commission would have been presided over by a Socialist, and the 1999 centre-left Prodi Commission would have been presided over by a Conservative (reflecting the new dominance of the European People's Party [EPP] in the European Parliament). But, if the Commission had been elected by a fullyfledged parliamentary model, a 'grand coalition' of Conservatives and Socialists would have resulted in all periods except 1999, which would have been a centre-right coalition of Conservatives, Liberals and Gaullists. Finally, with a two-thirds majority, the only feasible coalition in all periods would have been a grand coalition of Socialists and Conservatives, and in some cases other parties would also have been needed.

Basically, any parliamentary model for electing the Commission would have resulted in a rather different Commission than the ones chosen by the governments, and rather different policy outcomes. For example, a parliamentary model may have meant that the Single Market Programme would not have been supported so enthusiastically by the Commission because throughout the 1980s the Commission would have been dominated by 
the centre-left! In contrast, a quasi-presidential model, with the Commission President elected by national parliaments, would have produced an EU executive more similar to the majority in the Council yet independent from their direct influence because of the separationof-powers system.

In section 2, we describe the current mechanism for the appointment of the Commission. In section 3, we describe the make-up of the European Parliament since 1979. In section 4, we explain our five scenarios for the election of the European executive. In section 5, we comment on the results obtained and discuss the merits of the various proposals on the table in the light of our simulations. In section 6, we summarise the main findings and conclude in favour of the election of the Commission President by national parliaments.

\section{How the Commission is Currently Elected: Unanimity in the European Council}

Under the Treaty of Rome, the Commission is chosen by 'common accord' amongst the EU Heads of Government. In practice this has meant that the Commission has been elected by unanimity amongst the EU governments. The governments appoint the Commission President by unanimity, each government then nominates its own Commissioners, the governments then formally adopt the College of Commissioners by unanimity.

In the 1993 Maastricht Treaty, the European Parliament was given the right to be 'consulted' on the governments' nominee for Commission President - which the Parliament interpreted as a formal right to veto the proposed candidate (Hix, 2002a). In the 1999 Amsterdam Treaty, the governments formally granted the Parliament a right to veto the governments' choice both of the Commission President and of the Commission as a whole. Finally, in the Nice Treaty, with the prospect of enlargement of the EU to twenty-five or more 
member states, the governments maintained their monopoly on the nomination of the

Commission, but agreed that the appointment should be made by a qualified-majority in the European Council rather than by unanimity.

However, as the Nice Treaty only entered into force in 2002, no Commission has been elected using the qualified-majority rule. The Santer Commission was the only executive to be elected under the Maastricht Treaty procedure, and the Prodi Commission was the only executive to be elected under the Amsterdam Treaty procedure. The next Commission, elected after the 2004 European elections will probably be the only executive elected under the Nice (qualified-majority) rules, as the next-but-one-Commission (probably in 2009) will be chosen under the rules established in the new EU constitution (assuming that the Nice status quo is changed).

\section{TABLE 1 ABOUT HERE}

The use of unanimity in the European Council has meant that the Commission has always reflected the partisan make-up of the governments at the time of the election of the Commission. The Commission is supposed to be politically neutral. But, there have been political shifts in the composition of the Commission over time as the political composition of national governments has shifted. As Table 1 shows, the centre-right majority in the Council throughout the 1980s and early 1990s produced a centre-right majority in the six Commissions in this period (Thorn, Jenkins, Delors I, Delors II, Delors III, and Santer). Even though Jenkins and Delors were Socialists, Table 1 shows that the socialists only formed 38 percent of the Jenkins Commission, and respectively 43, 41 and 29 percent in the three Delors Commissions. All other Commissioners came from the centre- right. Similarly, the centreleft majority in the Council in the late 1990s produced a centre-left majority in the Prodi 
Commission: which has 55 percent of Commissioners on the left (Socialist or Green), and 45 percent of Commission on the right (Liberal, EPP or non-EPP Conservatives).

Also, it should be pointed out that although the Commission seeks to reach consensus when proposing legislation, formally it can decide by a simple-majority (with the

Commission President holding the casting vote). As a result, the party-political make-up of the Commission does make a difference. For example, the single market project of the late 1980s and early 1990s was driven by centre-right majority in the Council, supported by a centre-right majority in the Commission - despite the existence of a Socialist (Delors) at the helm. Similarly, in the late 1990s the drive to introduce a series of directives in the social affairs field (on working time, workers consultation, non-discrimination on the grounds of race etc.) was pursued by centre-left majorities in the Commission and Council, against a centre-right majority in the post-1999 European Parliament.

The question, then, is how would this have been different had the Commission been elected by the European Parliament rather than the Council? To do this, we first look at the evolution of the composition of the European Parliament since 1979.

\section{The European Parliament Since 1979}

Table 2 shows the partisan make-up of the European Parliament just after each of the five direct-elections. The first two parliaments had slight centre-right majorities, with the European People's Party (EPP), the French Gaullists and their allies (GAU), the British Conservatives and their allies (CON), and the Liberals (LIB) commanding 58 percent and 51 percent of the seats, respectively. The third parliament was evenly balanced, with the parties on the left - the Socialists (SOC), Greens (GRN), Radical Left (LEFT) and Regionalists 
(REG) (who were mostly on the left) - commanding 48 percent of the seats compared to 47 percent for the parties on the right. This was also the case in the fourth parliament, with both the left and right on 44 percent. Finally, in the fifth parliament, the centre-right returned to the majority, with just over 50 percent of the seats.

\section{TABLE 2 ABOUT HERE}

On that arithmetic basis alone, it would be difficult to tell what majority would form in each parliament, especially in the evenly-balanced third and fourth parliaments. Even when there seems to be a clear arithmetic majority, as in the fifth parliament, one must however also be careful since the left-right dimension is clearly not the only relevant dimension for the formation of political coalitions in EU politics. This is especially in the European Parliament, where research on individual-level MEP voting behaviour finds that both the left-right and the pro- and anti-European integration dimensions are salient (e.g. Kreppel and Tsebelis, 1999;

Hix, 2001; Noury, 2002; Noury \& Roland, 2002).

As a result, looking at individual level voting behaviour in the parliament provides a more accurate picture on which to base a counterfactual analysis. Figure 1 shows the result of applying the NOMINATE method of individual legislator ideal point estimate to all 2,124 roll-call votes in the first half (1999-2001) of the fifth parliament. Each dot in the figure represents the 'revealed' ideal point of an individual MEP on the two main dimensions of EU

politics: left-right (with -1.0 the furthest left and +1.0 the furthest right) and pro-/antiintegration (with -1.0 the most anti-integration and +1.0 the most pro-integration). The distance between any two MEPs reveals the frequency with which these two legislators voted together. If two MEPs are in exactly the same point, they voted exactly the same way in 
every vote in this period, whereas if the MEPs are at opposite ends on both dimensions, then they voted on different sides on every issue.

\section{FIGURE 1 ABOUT HERE}

As the figure reveals, most party groups in the fifth parliament where relatively cohesive, with the MEPs in these groups tightly bunched around a party median. The NOMINATE results clearly show the left-right spectrum on the first (horizontal) dimension: Green and Radical Left at the extreme Left, the Socialists to the Left and the EPP to the right. Also, the location of the Liberals approximately half-way between the two main groups reveals that these MEPs voted as much with the Socialists as with the European People's Party when issues split the parliament along left-right lines. Nonetheless, the MEPs' positions on the second dimension reveal that the three main groups (SOC, EPP and LIB) tended to vote together against the smaller groups of the extreme left and right as well as the Gaullists when issues split the parliament on pro-/anti-integration lines.

\section{TABLE 3 ABOUT HERE}

Table 3 shows the mean position of the party groups on these two dimensions in all five parliaments. The position of the Liberals is particularly interesting. The distances between this group and the Socialists and EPP on the first dimension shows that the Liberals voted more with the right in the first three parliaments, but voted more or less equally with the these two main parties in the fourth and fifth parliaments.

From the individual MEP NOMINATE scores we calculate the two-dimensional Euclidean distance between each MEP in each parliament. This information allows us to 
construct a series of counterfactual scenarios about who would have governed Europe had the European Parliament had the power to elect the EU executive.

\section{Five Scenarios for Electing the EU Executive}

Using the two-dimensional MEPs' NOMINATE scores we model four different scenarios of an election of the Commission by the European Parliament.

In the first scenario we assume that the parliament elects the Commission President (and that the College of Commissioners is then formed subsequently), and that MEPs follow the voting instructions of their European Parliament party groups. This is a reasonable approximation of how roll-call voting in the parliament works in practice. In roll-call votes, how each MEP has voted is recorded in the minutes, and can hence be monitored by the party group leaders. In previous research, we found high levels of party group cohesion in roll-call votes in all five parliaments, and increased voting along party lines and decreased voting along national lines over time (Hix, Noury and Roland, 2002; Noury and Roland, 2002).

To operationalize this we assume that each party group nominates a candidate, and that the election of the Commission President is conducted as a multi-round contest, with the candidate with the lowest votes being eliminated in each round, and the contest continuing until a candidate has secured fifty-percent-plus-one of the votes. ${ }^{2}$ From the NOMINATE positions of the MEPs, we calculated the median position of each party group on each dimension, and chose the MEPs closest to these locations as the candidates of each group. We then calculated the two-dimensional Euclidean distance of each party group from these

\footnotetext{
${ }^{2}$ This style of multi-round contest is the method the European Parliament uses for electing its senior offices, such as the President of the Parliament, and hence is probably how the parliament would chose to elect a Commission President.
} 
candidates, and assumed that each party group votes en bloc for the candidate closest to its two-dimensional median position.

In the second scenario the Parliament still elects the Commission President, but this time we assume that MEPs vote according to their personal ideological positions in the twodimensional space of EU politics. This assumption can be justified as an approximation of what might happen if the vote were taken by secret ballot, which would free the MEPs from pressure from either their national party leaders or their European Parliament party groups. ${ }^{3}$ For example, in implementing the Nice Treaty, the European Parliament changed its rules of procedure (in July 2002), so that the vote in the European Parliament on the nominee for Commission President (who would be chosen by a qualified-majority in the European Council) would be by secret ballot rather than by roll-call.

To operationalize this we again assume that each party group nominates a candidate, and that the election is conducted as a multi-round contest. However, from the NOMINATE positions of the MEPs, we calculated the two-dimensional Euclidean distance of each MEP from these candidates, and assumed that each MEP votes for the candidate closest to his/her two-dimensional location.

\section{TABLE 4 ABOUT HERE}

Table 4 illustrates how these two scenarios play out in the fifth parliament. Interesting, if the MEPs follow party groups lines, the candidate of the EPP would win the contest. But, if the MEPs vote independently, the candidate of the Liberals would sneak through to beat the EPP candidate in the final round. These are not unreasonable outcomes if

\footnotetext{
${ }^{3}$ Another possible assumption could be that MEPs vote along national party lines. However, in practice this would be almost identical to MEPs voting according to their personal positions. This is because most national party delegations of MEPs are highly cohesive, which means that MEPs from the same national party tend to have very similar NOMINATE scores.
} 
one considers that an EPP candidate (Nicole Fontaine) was elected President of the Parliament for the first half of this parliament's term and a Liberal candidate (Pat Cox) was elected President for the second half of the parliament's term. Looking more closely at Table 4 allows us to understand the difference between both scenarios. In the first scenario, the Anti-Europeans (ANTI) get an important head-start, as the Gaullists drop out and support the Anti-Europeans in round 2. In round 3, the Radical Left drop out in favour of the Greens. The Liberals are the smallest group in that round and drop out in favour of the EPP in round 4. The EPP in turn benefits in round 5 from support from the Gaullists to get an absolute majority against the Socialist and Green candidates. In the second scenario, the Liberals are able to exploit their pivotal position in the parliament to attract votes in successive rounds from the MEPs to their left against the EPP candidate.

In the third scenario, we assume that the parliament elects the Commission as a whole, through a process of 'government formation' amongst the groups in the parliament modelled on the classic parliamentary model of government formation in the domestic arena in Europe.

To operationalize this we assume that only 'connected' coalitions can form: where party groups prefer coalition partners that a closest to them over coalition partners that are further away. To work out which coalition is the most likely to form, we assume that each party group has a probability of being chosen as the coalition formateur in relation to their proportion of seats in the parliament. We then calculate the ideal 'minimum-connectedwinning' coalition preference of each party. The formateur forms a coalition with the party closest to it first (in terms of a two-dimensional Euclidean distance), then the next closest second, and so on until the coalition partners command fifty-percent-plus-one of the seats. But, if a party group takes the coalition partner well over the fifty-percent-plus-one threshold, and any parties in the coalition are surplus for a minimal-winning majority, then these surplus 
parties are dropped, in order of the furthest away first. Finally, if two parties form the same winning-coalition, we calculate the probability of this government forming as the combined probabilities of these parties being chosen as formateurs (in other words, the combined proportion of seats of these two parties).

\section{TABLE 5 ABOUT HERE}

Table 5 illustrates how this scenario works in the fifth parliament. If the EPP is the formateur, it chooses the Liberals (LIB) first, then chooses the Gaullists (GAU) to bring the coalition over the fifty-percent threshold. In contrast, the Socialists choose the Liberals first, then the Greens (GRN), then the EPP. But, at this point, the Liberals and Greens are surplus to a minimum-winning coalition, which means that the preferred coalition of the Socialists is a SOC-EPP 'grand coalition'. However, because the Liberals and Gaullists would form the same coalition as the EPP, the EPP-LIB-GAU is the most likely simple-majority-winning government to be formed in the fifth parliament, with a probability of 50.4 percent.

In the fourth scenario, we assume an identical process of government formation (through a minimum-connected-winning-coalition), but that the coalition must command twothirds support in the parliament, rather than a simple majority - in other words, as a way of operationalizing the Commission's proposal to the Convention.

Finally, in a fifth scenario we assume a separation of powers between the Commission and the Parliament, and that the Commission President is elected via an electoral college of national parliaments in the same year as the European Parliament election (cf. Hix, 2002b; Berglöf et al. 2003). To operationalize this we assume that each European party (as constituted by the party groups in the parliament) proposes a candidate. National parties vote en bloc for the candidate that is put forward by the party group in which they sit in the 
European Parliament. We start from the number of MPs each national party had at the time of the European Parliament election (June 1979, June 1984, June 1989, June 1994, and June 1999). The votes of each national party are then weighted by the proportion of MEPs from their member state (in other words, each national party has a proportion of votes equal to their proportion of national MPs multiplied by the proportion of MEPs from their member state).

The contest is held over two rounds, with the two candidates winning the most votes in the first round going through to a run-off contest. In practice this means a run-off between the Socialist and EPP candidates. In the second round, we assume that the national parties to the left of the Liberals vote for the Socialist candidate and the national parties to the right of the Liberals vote for the EPP candidate. Where the Liberals are concerned, we assume that the 'social liberal' parties (the British Liberal Democrats, Dutch D'66, Danish Radikale Venstre, Italian Radicals, Swedish Centre Party, and Finnish KESK) vote for the Socialist candidate, while all the other Liberal parties vote for the EPP candidate.

\section{TABLES 6 AND 7 ABOUT HERE}

Table 6 illustrates how such a 'presidential' election amongst national MPs would have worked in July 1999. Table 7 then illustrates the likely outcome of such a contest in all five periods.

\section{Results and Analysis}

Table 8 gives the summary results for the five scenarios for each of the five parliaments elected since 1979. 
TABLE 8 ABOUT HERE

The first line shows the result of the election of the Commission President by the European Parliament assuming party group discipline. The Commission President would have been a Conservative in all Parliaments except the 1994 Parliament, which would have been elected a Socialist Commission President. Note that such predictions cannot be made readily from the arithmetic composition of the European Parliament. For example, the shift in the position of the Liberals to the left in the fourth Parliament is the key factor that would have led to the election of a Socialist Commission President in this period. Note also that for the last two parliaments, the political colour of the Commission President would have been different from the political colour of the actual Commission. This is explained by the fact that the European Parliament elections are often protest votes against incumbent governments. Thus the fourth parliament was more to the left in the late 1980s and early 1990s when most European governments were on the centre-right, and then the European Parliament shifted strongly to the centre-right in the 1999 elections when Social Democrats where in government in most European countries.

The second line of the Table shows the outcome of a European Parliament election of the Commission President assuming no party group discipline (in other words, if a vote were taken by secret ballot). The main difference with the party discipline scenario is that in the third and fifth parliaments, a Liberal President would have been elected, as a result of the pivotal position of the Liberals in these parliaments (see Hix, Noury and Roland, 2002).

The third line shows the most likely coalition if the Commission were a normal parliamentary government; in other words, a coalition enjoying a simple majority in the European Parliament. It is striking to see that in the first four parliaments, there would have 
been a grand coalition between the Socialists and EPP, with the Radical Left part of the coalition after the 1984 election. Only the 1999 Commission would have been a right-wing coalition, of the Conservatives, Liberals and Gaullists.

The fourth line shows the coalition outcome with a two-thirds majority rule. The Socialists and Conservatives would again have to have been part of all coalitions, but the Radical Left would also have been part of the first two coalitions and the Liberals part of the last two.

In sum, the parliamentary model would have produced EU governed at the centre by the two big parties, possibly adjoined by a third. This is not a terribly exciting prospect in terms of democratic competition for executive office and alternation of governments. A parliamentary model in the EU would not produce a clear opposition force, which would not be good for the democratic accountability of the incumbents. Moreover, even with a 50 percent majority rule, the Radical Left would have been part of the 1984 Commission. This means that the Single Market Programme, pursued and implemented by the Commission in that period, would probably not have taken place!

The fifth line shows the result of the election of the Commission President in a tworound election by national parliaments. The Commission President would have been a member of the EPP in the first four periods and a Socialist in the fifth period. Note that this is the only scenario that follows closely the actual composition of the Commission. This is not surprising since the composition of the Council, that determined the composition of the actual Commission, is based on governing majorities in national parliaments.

We believe the above simulations are the most accurate to date and exploit data on the composition of the European Parliament as well as national parliaments at the time of the European Parliament elections. Table 8 shows that the various scenarios for appointment of the Commission do lead to different results. The main difference we observe in Table 8 is 
between the parliamentary scenarios (lines 1 to 4 ) and the presidential scenario (line 5). This difference is very much related to the fact that elections for the European Parliaments have been fought as 'second-order national contests', tending to favour the opposition parties in member states (van der Eijk and Franklin, 1996). This means that a parliamentary mode of selection of the Commission would tend to lead to a political composition of the Commission that would be very different from the political composition in the Council at the time of the appointment of the Commission. In our view, this 'built-in' form of 'divided government' would lead to unnecessary clashes between the Commission and the Council, which could be unproductive for the functioning of the European Union.

The above reasoning is however subject to several objections. First of all, voters may change their behaviour when voting for the European Parliament once the latter has the power to appoint the European executive. This is quite possible. However, one can expect a high degree of inertia in voting behaviour in European elections, particularly when one considers the incentives of national political parties in these contests - who would still desire to use European elections as national referendums on the performance of national governments (rather than of European government) regardless of whether these contests have an impact on the make-up of the Commission. As a result, elections for the European Parliament are likely to be second-order contests for quite some time, thus making the 'divided government' effect quite likely at least in the first few decades of the EU Constitution.

Second, the effect we are describing may be exaggerated since national elections take place continuously between two elections for the European Parliament. It is thus not clear whether on average one would observe forms of divided government or not. However, it is not impossible that national elections will become increasingly synchronized over time. Moreover, the 'divided government' effect would take place at the beginning of the tenure of 
each Commission, a most critical moment where a grace period would be needed to allow the new Commission a chance to get some legislation through.

Third, the 'divided government' effect would be limited if the rest of the Commission were appointed by the Council - as in our first scenario, where the European Parliament simply elects the Commission President. However, even in this case, the Commission President would be viewed with suspicion in the Council in the beginning of its tenure. This would not bode well for the legitimacy of the Commission. On the contrary, it is important that the Commission and the Council have a good working relationship to have a smooth functioning of the EU institutions. From this point of view, the presidential model is clearly better.

Does this mean that the European executive should continue to be elected by the Council? Not at all. We think there is a fundamental difference between the election by a majority in the Council and by a majority in national parliaments. Election of the Commission President by national parliaments gives the European executive a legitimacy that is independent from the Council. Independence of the Commission from a political majority in either of the EU's legislative institutions - the Council and the European Parliament - has been vital for the functioning of the EU, as this allows governments to make credible commitments to each other by delegating agenda-setting and implementation to a political actor which is not controlled by a particular faction in the legislature (esp. Dehousse, 1995; Majone, 1996, 2002; Pollack, 1997; Moravcsik, 1999).

In our opinion, though, independence of the Commission has not been secured because of particular legal requirements in the Treaty, where Article 213 states that 'The Members of the Commission shall ... be completely independent in the performance of their duties'. Rather, independence has been secured because prior to the Nice Treaty the Commission was elected by a unanimity rule in the Council (cf. Crombez and Hix, 2002). 
The fact that a much larger majority was required for electing the executive than for implementing its legislative proposals in practice meant a separation-of-powers system in the EU. Once the same majorities are used for both electing the Commission and for implementing its proposals - as would be the case either with the Nice Treaty reform (where the Commission would be elected by a qualified-majority in the Council) or if the Commission were elected by a majority in the European Parliament - there would be an end to the separation-of-powers system. This would mean an end to the independence of the Commission, and an end to the ability of governments to delegate to an executive body that is not captured by a legislative majority.

Moreover, the election of the president by national parliaments can be established through an 'electoral college' system, where each member state has a particular number of electoral college votes, which would reflect state interests as well as population size. A big advantage of such a system is that votes in national parliaments could be replaced by universal suffrage by the countries who choose so (Hix, 2002b; Berglöf et al., 2003). This could pave the way for the election of the President of the Commission by universal suffrage in the future. It is crucial however that each national parliament would have a number of electoral college votes equal to their representation in national parliaments and these votes would be proportional to the ballot result in each national parliament. Such proportionality avoids a 'winner take all' outcome in individual countries, as is the case with US states. This may seem like a detail of electoral law but it would avoid situations like the recent US presidential election where flaws in Florida's election decided the outcome of the presidency because a few thousand votes gave George W. Bush the electoral college vote for all Florida. By introducing this proportional rule, candidates for presidency would have to campaign in each country to gain votes, thereby avoiding the danger that individual countries would feel left out. Thus in this scenario, if votes are divided 51-49 percent in France between say a 
Socialist and a Conservative candidate, the electoral college votes of France would also be divided 51-49 percent among the two candidates.

There are a number of arguments that favour the choice of a presidential rather than a parliamentary system for Europe in the long run (see Berglöf et al., 2003 for a thorough discussion). First of all, a presidential system has strong accountability effects for the executive. The incumbent can more easily be punished in elections and replaced by a challenger. In a parliamentary system, the Conservatives and Socialists would tend to be part of most coalitions. They would thus fear less punishment by voters, which would make them less accountable. Second, a presidential system would have more executive effectiveness than a parliamentary system. The latter would always be a form of coalition government and decisions would have to be continuously negotiated within the coalition. More often than not, decisions would be made too late, as is often the case with coalition governments. Another advantage of the presidential over the parliamentary system is that it allow a genuine separation-of-powers between the executive branch and the legislative branch of government. This allow better checks and balances between both. Moreover, it leads to more decentralized forms of legislation: majorities on bills form on a case-by-case basis rather than on the basis of majority and opposition. This ensures that no group will systematically be in the minority.

The presidential system is less desirable when it comes to global expenditure programs like welfare programs - where parliamentary systems tend to produce more economic redistribution and public goods. However, this is not a big disadvantage in the EU context, as strong welfare states already exist at the domestic level in Europe, where member states have parliamentary models of government.

All in all, there is a case to be made for a presidential form of governance for Europe. Having the President of the Commission elected by national parliaments would be a good first step in that direction. 


\section{Conclusion}

In this paper, we used data from the European Parliament and national parliaments to ask what would have been the political composition of the Commission in 1979, 1984, 1989, 1994 and 1999 according to various scenarios currently proposed in the Convention on the Future of Europe. The main findings of this analysis can be summarised as follows.

First, the political character of the Commission would have been different had different rules been used to elect the EU executive. As we know from the political science and political economy literature, rules governing the election of the executive make a difference. These rules determine the political/partisan colour of the executive, which in turn shapes policy outcomes. Under the status quo procedures (pre-Nice), a centre-right majority in the Council meant a centre-right majority in the Commission, which in turn meant a liberal Single Market Programme and monetarist plan for Economic and Monetary Union supported by these two institutions. A different executive-selection procedure could have produced a Commission with a different political orientation, which would have meant different EU policies and institutional relations between the Commission, the Council and the European Parliament.

Second, if the Commission President had been elected by the national parliaments, he or she would have been a representative of the centre-right alliance of Christian Democrats and Conservatives (the European People's Party [EPP]) in all periods except the present one (1999 to today), where he would have been a representative of the Socialists (SOC). Interestingly, the presidential scenario closely follows the actual political composition of the 
Commission since 1979; where the Commission was dominated by the centre-right until the current Prodi Commission.

Third, and in contrast, the colour of the Commission President would have been very different if he/she had been elected by the European Parliament. For example, if MEPs vote along party lines, the European Parliament would have elected a Socialists in 1994 instead of the centre-right Jacques Santer, and a Conservative in 1999 instead centrist Romano Prodi. But, if MEPs follow their personal preferences, the European Parliament would have elected a Liberal Commission President in 1989 and 1999. If the Commission had been elected by a fully-fledged parliamentary model, a 'grand coalition' of Conservatives and Socialists would have been the most likely outcome, except in 1999, when a centre-right coalition of Conservatives, Liberals and Gaullists (GAU) would have results. And, with a two-thirds majority, Socialists and Conservatives would have been part of all coalitions, but other parties would have to have been included in all parliaments except 1989 to secure a large enough majority.

Overall, any form of parliamentary model for electing the Commission would have produced a Commission with a very different partisan hue than the Commissions that were chosen by the EU governments. This is related to the fact that elections in the European Parliament are often protest votes against incumbent governments, which ensures that the political majorities in the Council and the Parliament are different. Any form of appointment of the European executive by the European Parliament would thus tend to create a built-in bias towards a political composition of the Commission that would be different from the political composition in the Council. This would create unnecessary conflicts between the Council and the Commission, which would be harmful for the EU, since one of the main objectives of the Convention is to make the Commission more accountable and to reduce the democratic deficit. Election of the Commission President by national parliaments would 
avoid this conflict while strongly enhancing the democratic accountability of the Commission and create an original system of separation of powers for Europe.

One effect driving these results is that the composition of the European Parliament is determined by a 'protest vote'. Thus, centre-right dominated fifth parliament was elected at a time when most European governments where on the left. On the other hand, election of the Commission President by national parliaments will tend to reflect the majorities in national parliaments at the time of the vote. As we discussed, election of the Commission President by national parliaments will have the advantage of a clear separation-of-powers and give the European Parliament a clear autonomy with respect to the European executive. Our simulations show that the presidential model is less likely to lead to political clashes between the Council and the Commission, a clear danger with any appointment of the Commission by the European Parliament.

While we have emphasized the disadvantages of forms of appointment of the European executive by the European Parliament, the worst of all possible worlds would be the Chirac-Schroeder institutional compromise, where the Commission President is elected by the European Parliament and a new single Council President is elected by the Council. This would create a dual executive with competing mandates, which could be disastrous for the EU, as has been pointed out by various commentators (such as Berglöf et al., 2003). Furthermore, as our analysis shows, this conflict would be exacerbated by the fact that the Presidents of the Commission and Council would in all likelihood be from opposite sides of the political divide.

If the Convention delegates were truly wise they would not choose either this flawed compromise or the parliamentary model but would instead opt for a presidential model of government for Europe. 


\section{References}

Bednar, Jenna, William N. Eskeridge and John Ferejohn (2001) 'A Political Theory of Federalism', in John Ferejohn, Jack N. Rakove and Jonathan Riley (eds)

Constitutional Culture and Democratic Rule, New York: Cambridge University Press.

Berglöf, Erik, Barry Eichengreen, Gérard Roland, Guido Tabellini and Charles Wyplosz (2003) Built to Last. A political Architecture for Europe, CEPR report Monitoring the European Economy No 12, CEPR London.

Blair, Anthony (2002) ‘A clear course for Europe’, speech in Cardiff, 28 November 2002.

Brok, Elmar (2002) Constitution of the European Union, CONV 325/02, Brussels:

Convention on the Future of Europe.

Commission of the European Union (2002) For the European Union: Peace, Freedom, Solidarity - Communication of the Commission on the Institutional Architecture, COM (2002) 728 final.

Crombez, Christophe and Simon Hix (2002) 'Unaccountable Brussels Bureaucrats? Implications of Constitutional Reforms for the Democratic Accountability of the EU', mimeo.

Dehousse, Renaud (1995) 'Constitutional Reform in the European Community: Are there Alternatives to the Majoritarian Avenue?', in Jack Hayward (ed.) The Crisis of Representation in Europe, London: Frank Cass.

Diermeier, Daniel and Timothy J. Feddersen (1998) 'Cohesion in Legislatures and the Vote of Confidence Procedure', American Political Science Review 92: 611-621.

van der Eijk, Cees and Mark Franklin (eds) (1996) Choosing Europe? The European Electorate and National Politics in the Face of Union, Ann Arbor: University of Michigan Press. 
Fischer, Joschka (2000) 'From Confederacy to Federation: Thoughts on the Finality of European Integration', speech at Humboldt University, Berlin, 12 May 2000.

Hix, Simon (2001) 'Legislative Behaviour and Party Competition in the European Parliament: An Application of Nominate to the EU', Journal of Common Market Studies 39: 663688.

Hix, Simon (2002a) 'Constitutional Agenda-Setting Through Discretion in Rule

Interpretation: Why the European Parliament Won at Amsterdam', British Journal of Political Science 32: 259-80.

Hix, Simon (2002b) Linking National Politics to Europe, London: Foreign Policy Centre.

Hix, Simon, Abdul Noury and Gérard Roland (2002) 'Understanding the European Parliament: Party Cohesion and Competition, 1979-2001', mimeo.

Huber, John (1996) 'The Impact of Confidence Votes on Legislative Politics in Parliamentary Systems', American Political Science Review 90: 269-282.

Kreppel, Amie and George Tsebelis (1999) 'Coalition Formation in the European Parliament', Comparative Political Studies 32: 933-966.

Laver, Michael, Michael Gallagher, Michael Marsh, Robert Singh and Ben Tonra (1995) Electing the President of the European Commission, Trinity Blue Papers in Public Policy: 1, Dublin: Trinity College, 1995.

Lijphart, Arend (1992) 'Introduction', in Arend Lijphart (ed.) Parliamentary Versus Presidential Government, Oxford: Oxford University Press.

Majone, Giandomenico (1996) Regulating Europe, London: Routledge.

Majone, Giandomenico (2002) 'The European Commission: The Limits of Centralization and the Perils of Parliamentarization', Governance 15: 375-392.

Moravcsik, Andrew (1999) ‘A New Statecraft? Supranational Entrepreneurs and International Cooperation', International Organization 53: 267-306. 
Noury, Abdul (2002) 'Ideology, Nationality and Euro-Parliamentarians', European Union Politics 3: 33-58.

Noury, Abdul and Gérard Roland (2002) 'More Power to the European Parliament?', Economic Policy 34: 279-320.

Persson, Torsten, Gérard Roland and Guido Tabellini (1997) ‘Separation of Powers and Political Accountability', Quarterly Journal of Economics 112: 1163-1202.

Persson, Torsten, Gérard Roland and Guido Tabellini (2000) 'Comparative Politics and Public Finance', Journal of Political Economy 108: 1121-1161.

Pollack, Mark A. (1997) 'Delegation, Agency and Agenda Setting in the European Community', International Organization 51: 99-134.

Poole, Keith T. and Howard Rosenthal (1997) Congress: A Political-Economic History of Roll Call Voting, Oxford: Oxford University Press.

Shugart, Matthew S. and John M. Carey (1992) Presidents and Assemblies: Constitutional Design and Electoral Dynamics, Cambridge: Cambridge University Press.

Tsebelis, George (2002) Veto Players: How Political Institutions Work, Princeton: Princeton University Press.

Verhofstadt, Guy (2002) 'Montesquieu and the European Union', speech at the College of Europe, Bruges, 18 November 2002. 


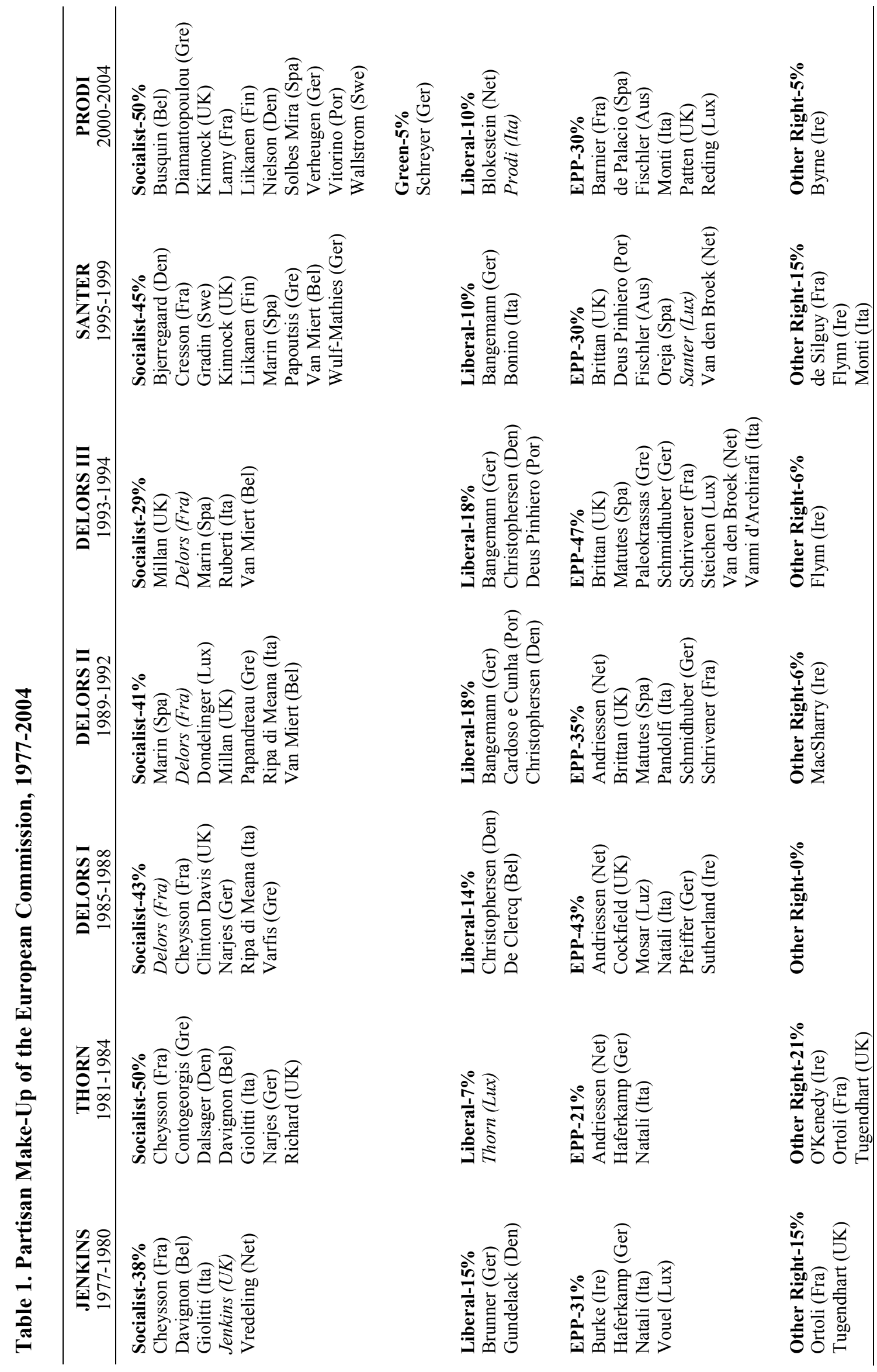

N 


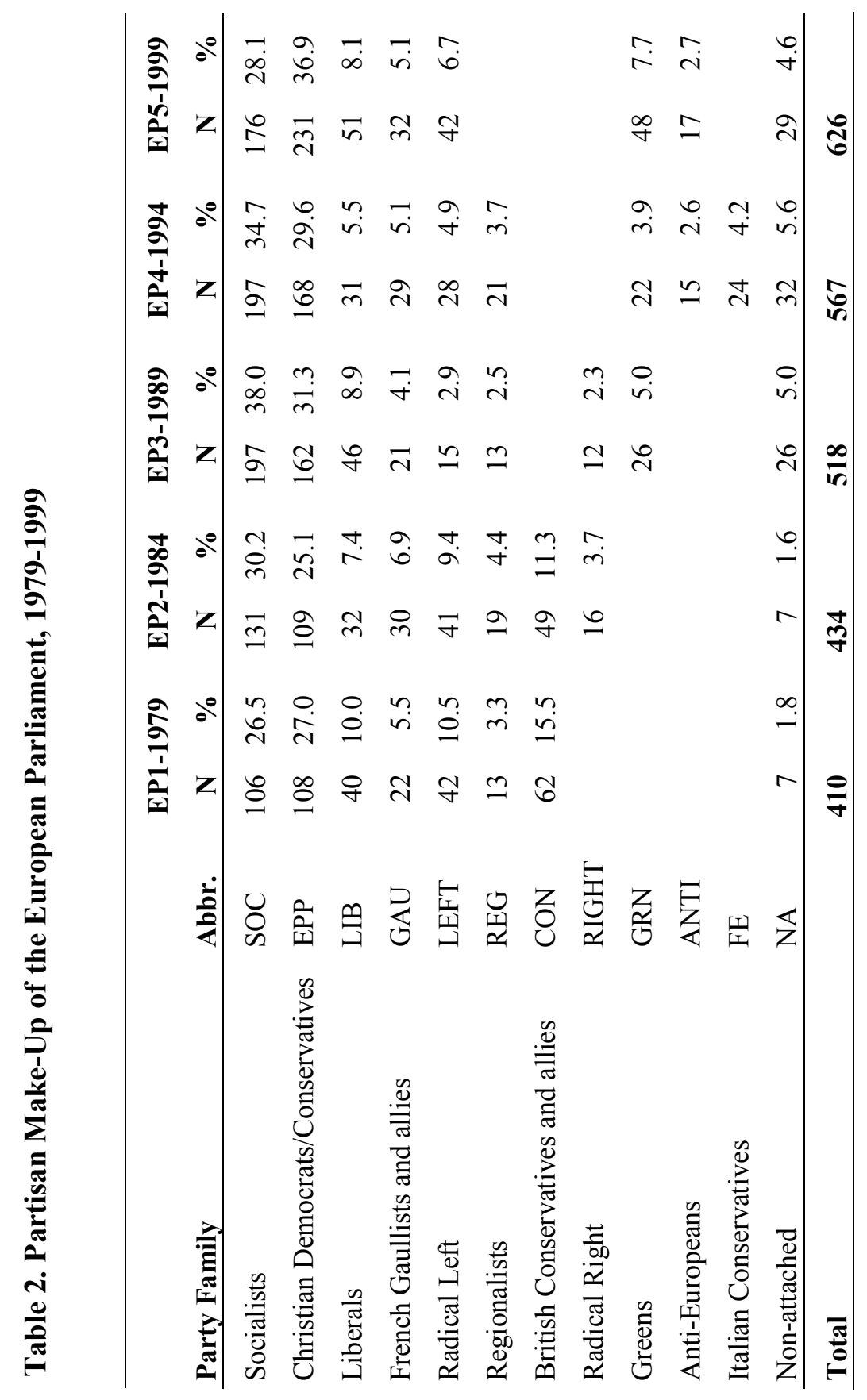




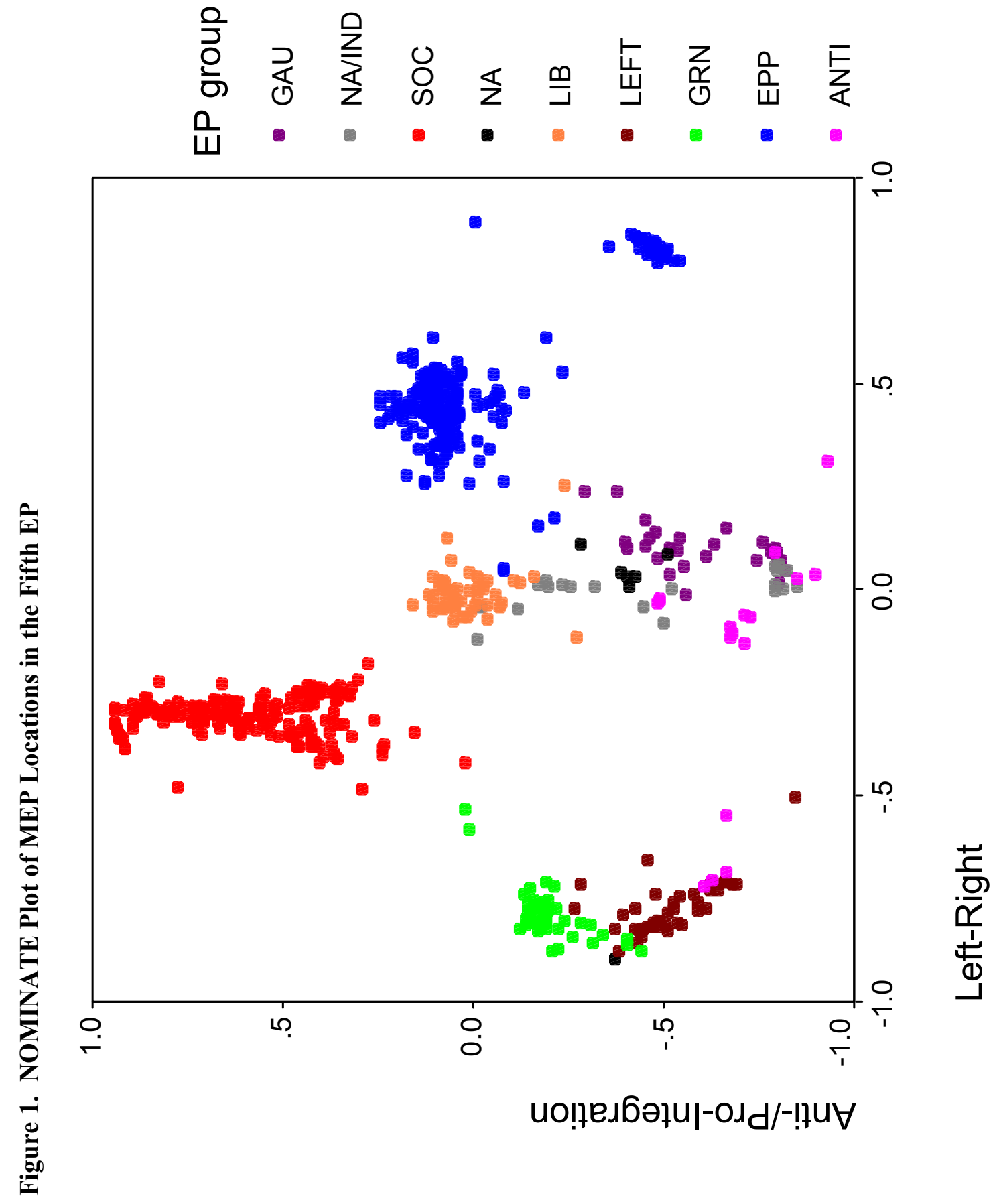

ิ 


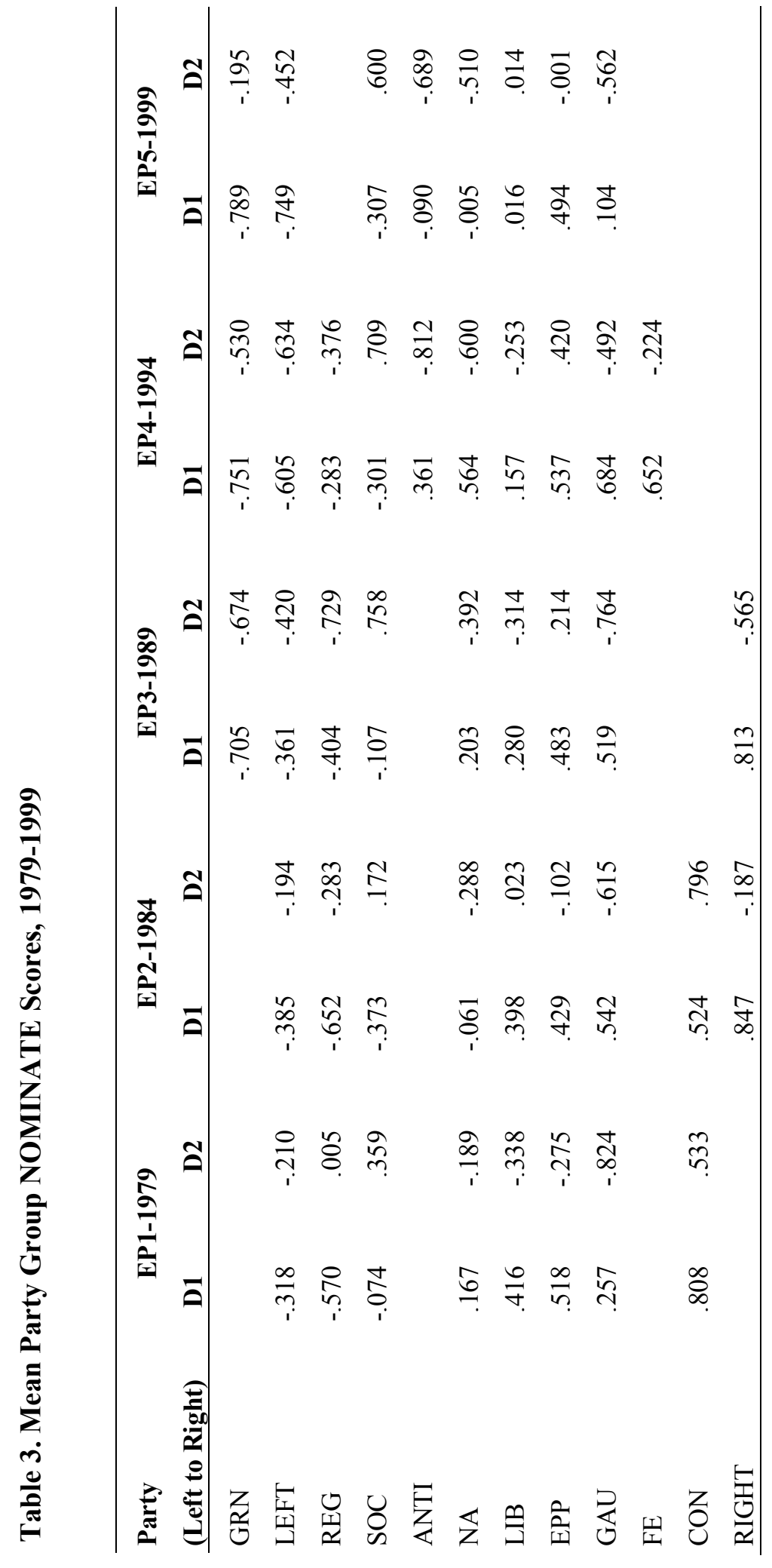



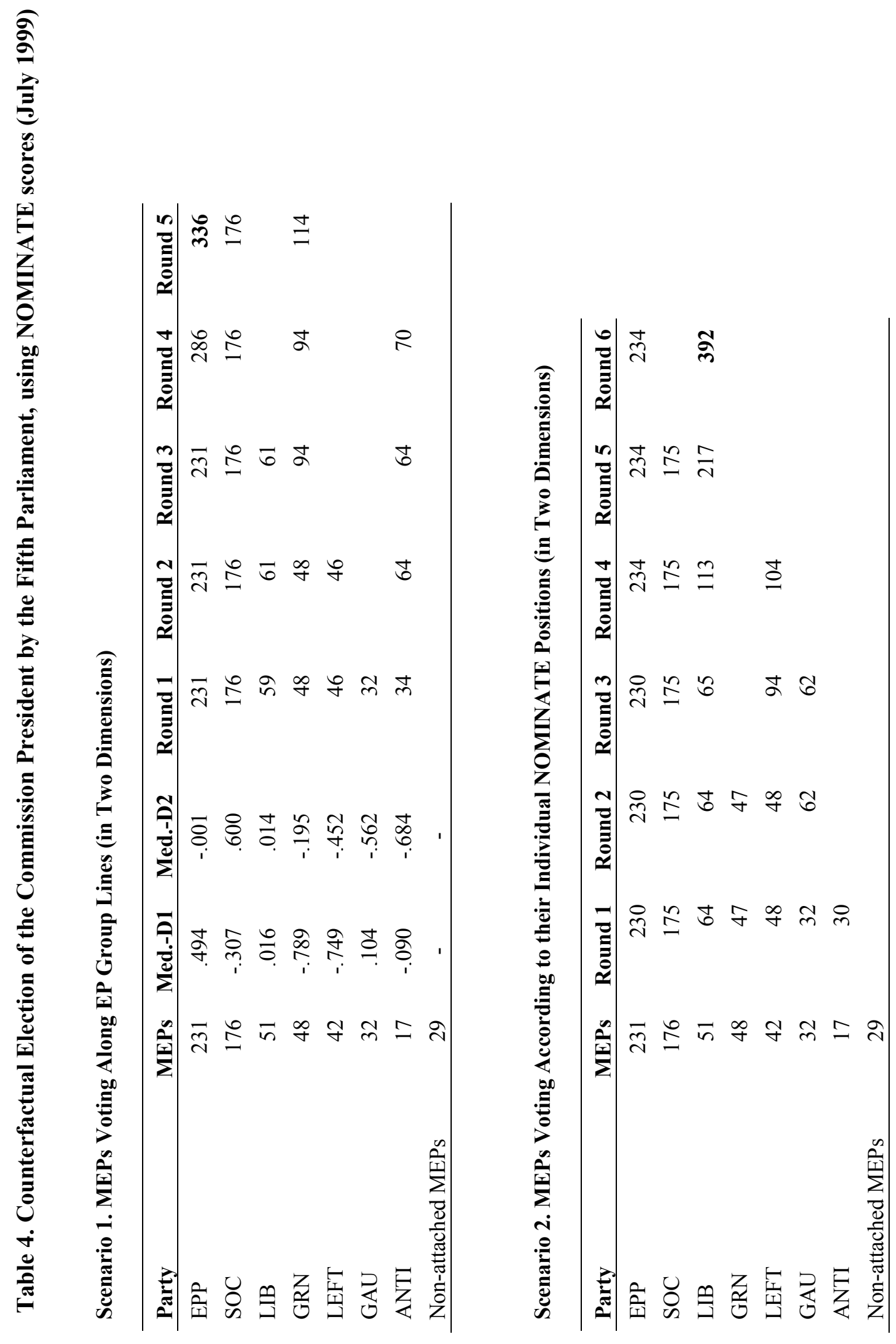


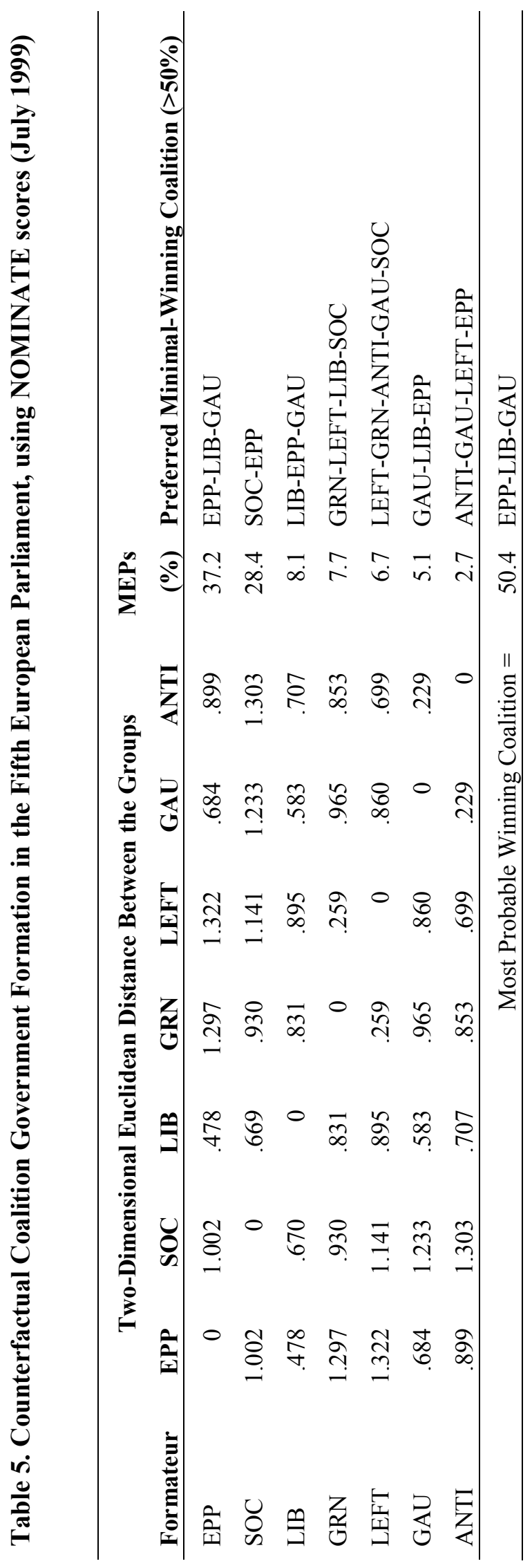


Table 6. Example of a National Parliament Election of the Commission President, 1999

\begin{tabular}{|c|c|c|c|c|c|c|c|c|c|c|c|c|c|}
\hline $\begin{array}{l}\text { National } \\
\text { Party } \\
\end{array}$ & MPs & $\begin{array}{r}\text { MPs } \\
(\%) \\
\end{array}$ & $\begin{array}{c}{ }^{*} \text { MEPs } \\
(\%)\end{array}$ & $\begin{array}{c}= \\
\text { Votes }\end{array}$ & $\begin{array}{l}\text { Support } \\
\text { Round } 1 \\
\end{array}$ & $\begin{array}{l}\text { Support } \\
\text { Round } 2 \\
\end{array}$ & $\begin{array}{l}\text { National } \\
\text { Party }\end{array}$ & MPs & $\begin{array}{r}\text { MPs } \\
(\%) \\
\end{array}$ & $\begin{array}{c}* \text { MEPs } \\
(\%)\end{array}$ & $\begin{array}{c}= \\
\text { Votes }\end{array}$ & $\begin{array}{l}\text { Support } \\
\text { Round } 1 \\
\end{array}$ & $\begin{array}{l}\text { Support } \\
\text { Round } 2 \\
\end{array}$ \\
\hline SPD & 298 & 44.5 & 15.8 & 7.04 & $\mathrm{SOC}$ & $\mathrm{SOC}$ & PASOK & 162 & 54.0 & 4.0 & 2.16 & $\mathrm{SOC}$ & $\mathrm{SOC}$ \\
\hline Grune & 47 & 7.0 & 15.8 & 1.11 & GRN & SOC & KKE/SYN & 30 & 10.0 & 4.0 & 0.40 & LEFT & SOC \\
\hline FDP & 43 & 6.4 & 15.8 & 1.02 & LIB & EPP & Portugal & & & & & & \\
\hline PDS & 36 & 5.4 & 15.8 & 0.85 & LEFT & $\mathrm{SOC}$ & PS & 115 & 50.0 & 4.0 & 2.00 & SOC & SOC \\
\hline RPR & 140 & 24.4 & 13.9 & 3.40 & GAU & EPP & PP & 15 & 6.5 & 4.0 & 0.26 & GAU & EPP \\
\hline $\mathrm{PR}+\mathrm{UDF}$ & 113 & 19.7 & 13.9 & 2.74 & EPP & EPP & Sweden & & & & & & \\
\hline $\mathrm{PCF}$ & 36 & 6.3 & 13.9 & 0.87 & LEFT & SOC & SAP & 131 & 37.5 & 3.5 & 1.32 & SOC & SOC \\
\hline NF & 1 & 0.2 & 13.9 & 0.02 & RIGHT & EPP & M & 82 & 23.5 & 3.5 & 0.83 & EPP & EPP \\
\hline Italy & & & & & & & $\mathrm{V}$ & 43 & 12.3 & 3.5 & 0.43 & LEFT & SOC \\
\hline $\mathrm{LN}$ & 59 & 9.4 & 13.9 & 1.30 & RIGHT & EPP & Austria & & & & & & \\
\hline $\mathrm{RC}$ & 35 & 5.6 & 13.9 & 0.77 & LEFT & SOC & SPO & 65 & 35.5 & 3.4 & 1.19 & SOC & SOC \\
\hline V & 21 & 3.3 & 13.9 & 0.46 & GRN & SOC & OVP & 52 & 28.4 & 3.4 & 0.95 & EPP & EPP \\
\hline Reg-R & 3 & 0.5 & 13.9 & 0.07 & EPP & EPP & FPO & 52 & 28.4 & 3.4 & 0.95 & RIGHT & EPP \\
\hline Reg-L & 1 & 0.2 & 13.9 & 0.02 & GRN & SOC & GRUNE & 14 & 7.7 & 3.4 & 0.26 & GRN & $\mathrm{SOC}$ \\
\hline UK & & & & & & & Denmark & & & & & & \\
\hline LAB & 419 & 63.6 & 13.9 & 8.84 & SOC & SOC & $\mathrm{S}$ & 63 & 36.0 & 2.6 & 0.92 & SOC & SOC \\
\hline $\mathrm{CON}$ & 165 & 25.0 & 13.9 & 3.48 & EPP & EPP & V & 42 & 24.0 & 2.6 & 0.61 & LIB & EPP \\
\hline LIB & 47 & 7.1 & 13.9 & 0.99 & LIB & SOC & $\mathrm{KF}$ & 16 & 9.1 & 2.6 & 0.23 & EPP & EPP \\
\hline UUP & 10 & 1.5 & 13.9 & 0.21 & ANTI & EPP & DF & 13 & 7.4 & 2.6 & 0.19 & ANTI & EPP \\
\hline $\mathrm{PC}$ & 6 & 0.9 & 13.9 & 0.13 & GRN & $\mathrm{SOC}$ & SF & 13 & 7.4 & 2.6 & 0.19 & LEFT & SOC \\
\hline SNP & 4 & 0.6 & 13.9 & 0.08 & GRN & SOC & $\mathrm{CD}$ & 8 & 4.6 & 2.6 & 0.12 & EPP & EPP \\
\hline Reg-L & 10 & 2.9 & 10.2 & 0.29 & GRN & SOC & VAS & 20 & 10.0 & 2.6 & 0.26 & LEFT & SOC \\
\hline Reg-R & 6 & 1.7 & 10.2 & 0.18 & EPP & EPP & SFP & 12 & 6.0 & 2.6 & 0.15 & LIB & EPP \\
\hline Netherlands & & & & & & & VIHR & 11 & 5.5 & 2.6 & 0.14 & GRN & $\mathrm{SOC}$ \\
\hline PvdA & 45 & 30.0 & 5.0 & 1.49 & SOC & SOC & $\mathrm{KD}$ & 10 & 5.0 & 2.6 & 0.13 & EPP & EPP \\
\hline VVD & 39 & 26.0 & 5.0 & 1.29 & LIB & EPP & Ireland & & & & & & \\
\hline $\mathrm{CDA}$ & 28 & 18.7 & 5.0 & 0.92 & EPP & EPP & $\mathrm{FF}$ & 77 & 46.4 & 2.4 & 1.11 & GAU & EPP \\
\hline D66 & 14 & 9.3 & 5.0 & 0.46 & LIB & $\mathrm{SOC}$ & FG & 54 & 32.5 & 2.4 & 0.78 & EPP & EPP \\
\hline GL & 11 & 7.3 & 5.0 & 0.36 & GRN & $\mathrm{SOC}$ & LAB & 17 & 10.2 & 2.4 & 0.25 & $\mathrm{SOC}$ & SOC \\
\hline $\mathrm{SGP} / \mathrm{G} / \mathrm{R}$ & 8 & 5.3 & 5.0 & 0.26 & ANTI & EPP & IND & 6 & 3.6 & 2.4 & 0.09 & LIB & EPP \\
\hline $\mathrm{SP}$ & 5 & 3.3 & 5.0 & 0.17 & LEFT & SOC & DL & 5 & 3.0 & 2.4 & 0.07 & LEFT & $\mathrm{SOC}$ \\
\hline Belgium & & & & & & & PD & 4 & 2.4 & 2.4 & 0.06 & LIB & EPP \\
\hline VLD & 23 & 15.3 & 4.0 & 0.61 & LIB & EPP & GP & 2 & 1.2 & 2.4 & 0.03 & GRN & $\mathrm{SOC}$ \\
\hline CVP & 22 & 14.7 & 4.0 & 0.59 & EPP & EPP & SF & 1 & 0.6 & 2.4 & 0.01 & LEFT & $\mathrm{SOC}$ \\
\hline PS & 19 & 12.7 & 4.0 & 0.51 & SOC & $\mathrm{SOC}$ & Luxembourg & & & & & & \\
\hline PRL-FDF & 18 & 12.0 & 4.0 & 0.48 & LIB & EPP & CSV & 19 & 31.7 & 1.0 & 0.30 & EPP & EPP \\
\hline VB & 15 & 10.0 & 4.0 & 0.40 & RIGHT & EPP & DP & 15 & 25.0 & 1.0 & 0.24 & LIB & EPP \\
\hline $\mathrm{SP}$ & 14 & 9.3 & 4.0 & 0.37 & SOC & $\mathrm{SOC}$ & LSAP & 13 & 21.7 & 1.0 & 0.21 & SOC & $\mathrm{SOC}$ \\
\hline ECOLO & 11 & 7.3 & 4.0 & 0.29 & GRN & SOC & ADR & 7 & 11.7 & 1.0 & 0.11 & EPP & EPP \\
\hline PSC & 10 & 6.7 & 4.0 & 0.27 & EPP & EPP & GRENG & 5 & 8.3 & 1.0 & 0.08 & GRN & SOC \\
\hline AGALEV & 9 & 6.0 & 4.0 & 0.24 & GRN & SOC & LENK & 1 & 1.7 & 1.0 & 0.02 & LEFT & LEFT \\
\hline $\mathrm{VU}$ & 8 & 5.3 & 4.0 & 0.21 & GRN & SOC & & & & & & & \\
\hline $\mathrm{FN}$ & 1 & 0.7 & 4.0 & 0.03 & RIGHT & EPP & & & & & & & \\
\hline
\end{tabular}




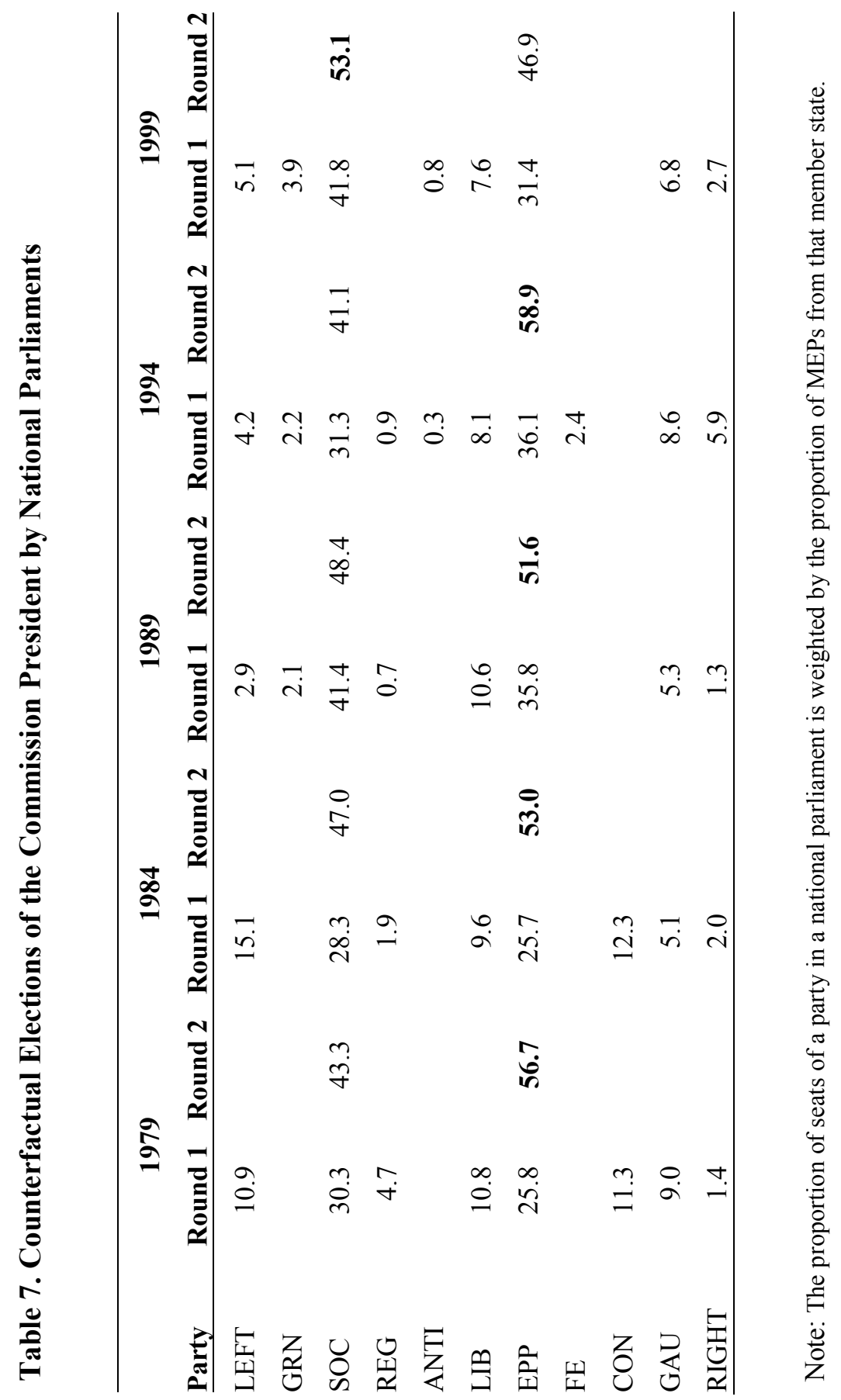




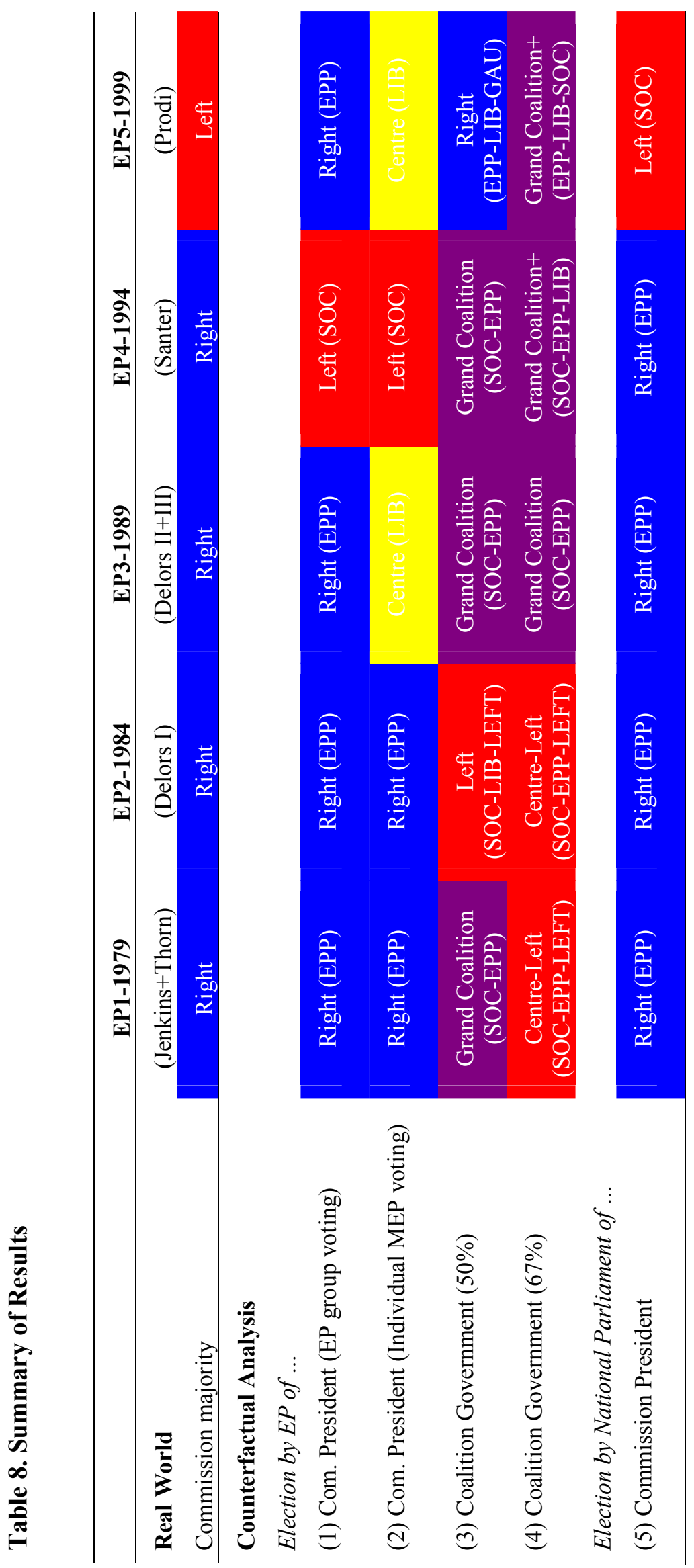

